\title{
Studies on Land Resource Inventory for Agricultural Land Use Planning in Northern Transition Zone of India through Remote Sensing and GIS Techniques
}

\author{
Denis Magnus Ken Amara ${ }^{1,2 *}$, Sayyadsaheb A. Nadaf', Daniel Hindogbe Saidu ${ }^{3}$, Osman S. Vonu4, \\ Raymond Morie Musa5, Philip Jimia Kamanda ${ }^{6}$, Patrick A. Sawyerr ${ }^{2}$, \\ Joseph Christian Adamu Mboma7, Saidu Deggy Mansaray², Mohammed Azim Sannoh²
}

\begin{abstract}
${ }^{1}$ Department of Soil Science \& Agricultural Chemistry, University of Agricultural Sciences Dharwad, Dharwad, India ${ }^{2}$ Department of Soil Science, School of Agriculture \& Food Sciences, Njala University, Njala Campus, Freetown, Sierra Leone ${ }^{3}$ Department of Agriculture, Food Security \& Livelihood, Sustainable Cassava Commercialization through Entrepreneurs Strengthening \& Support (SUCCESS) Project, BRAC, Bo, Sierra Leone

${ }^{4}$ Department of Soil Science, Eastern Technical University of Sierra Leone, Private Mail Bag, Kenema, Sierra Leone

${ }^{5}$ Department of Agricultural Education, Eastern Technical University of Sierra Leone, Private Mail Bag, Kenema, Sierra Leone ${ }^{6}$ Department of Extension \& Rural Sociology, School of Agriculture \& Food Sciences, Njala University, Freetown, Sierra Leone ${ }^{7}$ Department of Social Studies, Eastern Technical University of Sierra Leone, Private Mail Bag, Kenema, Sierra Leone Email: ^dmkamara@njala.edu.sl, „denismken@yahoo.com,drsanadaf@gmail.com,danielhsaidu@gmail.com, pjkamanda@njala.edu.sl,psawyerr@njala.edu.sl,cdvonu@yahoo.com,degeemans@gmail.com,raymondmusa208@gmail.com, jcmboma81@gmail.com, azimmohamed507@gmail.com
\end{abstract}

How to cite this paper: Amara, D.M.K., Nadaf, S.A., Saidu, D.H., Vonu, O.S., Musa, R.M., Kamanda, P.J., Sawyerr, P.A., Mboma, J.C.A., Mansaray, S.D. and Sannoh, M.A. (2021) Studies on Land Resource Inventory for Agricultural Land Use Planning in Northern Transition Zone of India through Remote Sensing and GIS Techniques. Journal of Geographic Information System, 13, 710-728.

https://doi.org/10.4236/jgis.2021.136039

Received: July 25, 2021

Accepted: December 27, 2021

Published: December 30, 2021

\begin{abstract}
Land suitability analysis is a prerequisite to achieving optimum utilization of available land resources. Hence, a study on land resource inventory for agricultural land use planning was conducted in the Northern Transition Zone of India to determine land capability and develop a suitability map for wheat and sorghum-based on physical and climatic factors of production using remote sensing and GIS techniques. Detailed soil survey information was used for this exercise. Four series (Singhanhalli, Mugli, Bogur and Venkatapur series) were identified and mapped into seventeen mapping units. Land capability classification showed that a greater portion of the study area belonged to class III followed by class IV with limitations of erosion, wetness and varying soil properties. Four land capability classes viz., II, III, IV, and VI, and seven subclasses viz., IIsf, IIItsf, IVs, IVt, IVts, IVtsf and VIt were identified. Major limitations of these subclasses were slope, erosion, depth, texture, coarse fragments, $\mathrm{pH}$, organic carbon and base saturation. Soil suitability assessment revealed that the soils are moderately suitable to permanently not
\end{abstract}


Copyright $\odot 2021$ by author(s) and Scientific Research Publishing Inc. This work is licensed under the Creative Commons Attribution International License (CC BY 4.0).

http://creativecommons.org/licenses/by/4.0/

Open Access suitable. About 234 ha (31.6\%) is moderately suitable, 494 ha $(65.0 \%)$ marginally suitable and 10.2 ha (1.3\%) permanently not suitable for wheat; while 78.5 ha $(10.3 \%)$ is moderately suitable, 633.4 ha $(82.3 \%)$ marginally suitable and 32.6 ha $(4.3 \%)$ permanently not suitable for sorghum respectively. The moderate, marginal and permanent non-suitability was due to moderate, severe and very severe limitations respectively. However, it is possible to achieve potential yield of the crops in the study area if these limitations are addressed.

\section{Keywords}

Land Resource Inventory, Soil Suitability, Land Use Planning, Land

Evaluation, Soil Survey, Remote Sensing, Soil Mapping

\section{Introduction}

Land use planning involves the evaluation of land for alternative land uses for the purpose of selecting the best land-use option from among multiple purposes including agriculture, pasture and forestry. Depending on the nature and properties of soils, land may be suitable for one or other uses. Based on the capability or limitations, lands are grouped into eight classes [1]. Among them, the first four classes (I - IV) of lands are used for cultivation of crops. These four classes are differentiated based on the extent of soil slope, erosion, depth, structure, soil reaction and drainage. The classes from V to VIII are not capable of supporting cultivation of crops but are however fit for other uses such as growing grasses, forestry and supporting wildlife and recreation. The classes V to VIII lands are normally delineated based on problems like streamflow, flooding, ponding, rocky nature, short growing season, snow cover, etc.

The land resources of Karnataka State Particularly Dharwad District are under severe threats due to competing demands of various land uses and increasing population pressure. According to [2] [3] [4], the increasing population and demand for food production and supply does not only lead to increased pressure on land per unit area but would cause further degradation [5]. Several studies on the land resources of Karnataka have been carried out [6]-[15] but most of information available is on a smaller scale, which cannot address site or location-specific issues. The generation of detailed site-specific soil and land resource information can help to identify the constraints and potentials of these scarce resources. This will help to provide suitable site-specific land use options, thereby helping to manage the scarce resources in a sustainable manner [16] [17] [18].

Information on soil and related properties obtained from the soil survey and soil classification can help in better delineation of soil and land suitability for irrigation and efficient irrigation water management. The performance of any crop is largely dependent on soil properties such as depth, drainage, texture, etc., 
as conditioned by climate and topography. The study of the soil-site characterization for predicting the crop performance of an area forms a part of land evaluation process. According to [19], land evaluation is the rating of soil for optimum returns per unit area. The yield influencing factors for important crops have to be evaluated and the results obtained may be applied for higher production of these crops through proper utilization of similar soils occurring elsewhere in similar agro-climate sub-region under scientific management practices [20]. Information on soil-site suitability evaluation for wheat and sorghum is not available for the study area. In view of this, the present study was carried out.

\section{Material and Methods}

\subsection{Description of Study Area}

Singhanhalli-Bogur micro-watershed has an area of 760.6 ha (Figure 1), and is located in the hot semi-arid agro-ecological region of India between latitude $15.60^{\circ} \mathrm{N}$ to $15.70^{\circ} \mathrm{N}$ and longitude $74.97^{\circ} \mathrm{E}$ to $74.98^{\circ} \mathrm{E}$ in the Dharwad Taluk of

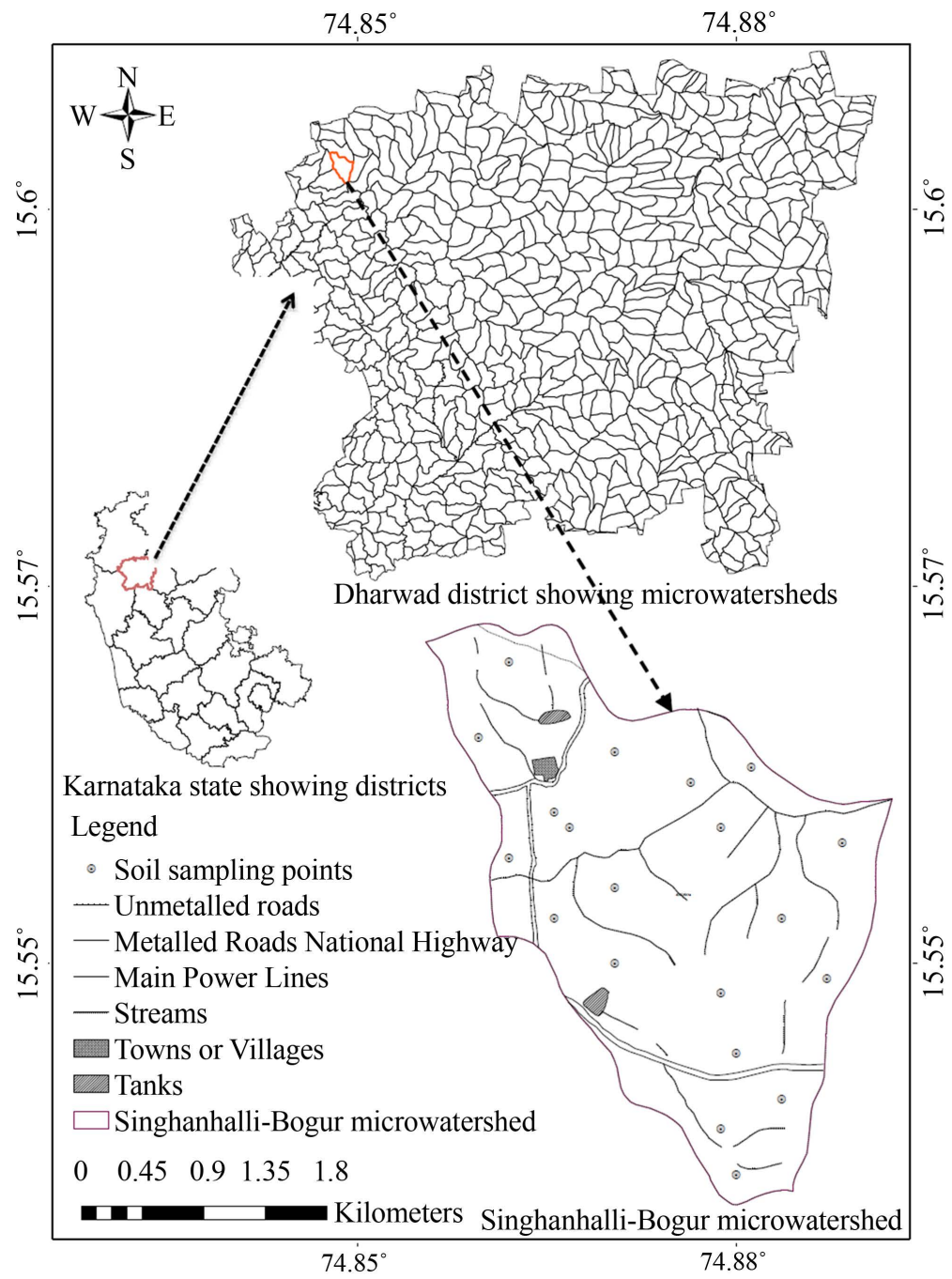

Figure 1. Map of study area. 
Dharwad District in the Northern Transition Zone of Karnataka State. This area has a medium to high available water content with a length of growing period of 150 - 180 days. The climate is characterized by hot and humid summer and mild and dry winter. The average annual rainfall is $755.2 \mathrm{~mm}$, which is distributed over May to October and annual temperature ranges from $24^{\circ} \mathrm{C}-28^{\circ} \mathrm{C}$ with a Ustic Soil Moisture and Isohyperthermic soil temperature regimes [21]. The highest elevation is $754 \mathrm{~m}$ above mean sea level and the relief is very gently to strongly sloping.

The general slope is towards the northeast, southeast and southwest but it is more in the southwest direction. The drainage pattern is parallel. Soils are derived from chlorite schist with shale as dominant parent material containing banded iron oxide quartzite. The soils are coarse-textured and shallow at the higher elevations but gradually, fineness and depth of particles increase towards the lower elevations. The main soil types are the black and red soils but the red soils are in a much higher proportion than the black soils. The natural vegetation is mainly comprised of trees and shrubs including Acacia (Acacia auriculiformis), Neem (Azadirachta indica) and Eucalyptus (Eucalyptus sideroxylon and Eucalyptus regnana).

\subsection{Soil Survey and Mapping}

A detailed soil survey of the study area was carried out using IRS P6 LISS-IV satellite image and Dharwad district Toposheet as per procedure outlined by [22], during which the area was intensively traversed and 20 pedon locations were fixed based on soil heterogeneity. At each pedon location, a fresh profile was opened and horizon-wise soil samples were collected and analyzed for important physical and physicochemical properties following standard analytical procedures. After the correlation of soil properties, soils were classified into four series according to "Keys to Soil Taxonomy" [23] and mapped into seventeen mapping units based on variation in texture, depth, slope and erosion.

\subsection{Land Capability and Soil Suitability Assessment}

The soil-site characteristics of different soil units were calculated as the weighted average of each soil property and interpreted for land capability and soil suitability for wheat and sorghum production in the study area. The properties were matched with the criteria for land capability classification and soil site suitability evaluation [2] [24] [25] (Tables 1-3). The land capability classification was mainly based on the inherent soil characteristics, external land features and environmental factors. The land capability classes and subclasses were arrived at as per the guidelines proposed in Soil Survey Manual [22] and soil-site suitability evaluation was done based on the FAO framework for land evaluation [2]. Soil-site suitability for wheat and sorghum was evaluated based on the criteria suggested by [25]. Land capability maps and soil-site suitability maps were prepared in the ArcView Interface of ArcGIS 10.1 software. 
Table 1. Criteria for land capability classification.

\begin{tabular}{|c|c|c|c|c|c|c|c|c|}
\hline Characteristics & Class I & Class II & Class III & Class IV & Class V & Class VI & Class VII & Class VIII \\
\hline \multicolumn{9}{|c|}{ Topography (t) } \\
\hline Slope (\%) & $0-1$ & $1-3$ & $3-8$ & $8-15$ & up to 3 & $15-35$ & $35-50$ & $>50$ \\
\hline Erosion & nil & slight & moderate & severe & nil & severe & very severe & \\
\hline \multicolumn{9}{|c|}{ Wetness (w) } \\
\hline Flooding & nil (F0) & $\begin{array}{l}\text { nil (F0) } \\
(\mathrm{F} 0 / \mathrm{F} 1)\end{array}$ & $\begin{array}{l}\text { nil to slight } \\
\text { (F1/F2) }\end{array}$ & & & & & \\
\hline Drainage (1) & well & mod. well & imperfect & poor & v. poor & excessive & excessive & excessive \\
\hline Permeability & moderate & mod. rapid & rapid, slow & $\begin{array}{l}\text { v. rapid, } \\
\text { v. slow }\end{array}$ & - & - & - & - \\
\hline $\begin{array}{l}\text { Infiltration rate } \\
\qquad\left(\mathrm{cm} \cdot \mathrm{hr}^{-1}\right)\end{array}$ & $2-3.5$ & $\begin{array}{l}1-2 \\
3-5\end{array}$ & $\begin{array}{c}0.5-1.0 \\
5-10\end{array}$ & $\begin{array}{l}<0.5 \\
>10\end{array}$ & 2.0 & & & \\
\hline \multicolumn{9}{|c|}{ Soil conditions (s) } \\
\hline Surface texture & 1 & sil \& cl & $\mathrm{sl} \& \mathrm{c}$ & scl & $\mathrm{s}, \mathrm{c}(\mathrm{m})$ & $\mathrm{ls}, \mathrm{cl}$ & ls, s, c & ls, s, c (m) \\
\hline $\begin{array}{l}\text { Surface coarse } \\
\text { fragments } \\
\quad(\operatorname{vol} \%)\end{array}$ & $1-3$ & $3-15$ & $15-40$ & $40-75$ & $15-75$ & $75+$ & & \\
\hline $\begin{array}{c}\text { Surface } \\
\text { stoniness (\%) }\end{array}$ & $<1$ & $1-3$ & $3-5$ & $5-8$ & $8-15$ & $15-40$ & $40-75$ & $>75$ \\
\hline $\begin{array}{c}\text { Subsurface } \\
\text { coarse } \\
\text { fragments (\%) }\end{array}$ & $<15$ & $<15$ & $15-35$ & $35-50$ & $50-75$ & $50-75$ & $50-75$ & $>75$ \\
\hline Soil depth $(\mathrm{cm})$ & $>150$ & $150-100$ & $100-50$ & $50-25$ & - & $25-10$ & $25-10$ & $<10$ \\
\hline $\begin{array}{c}\text { Profile } \\
\text { development }\end{array}$ & $\begin{array}{c}\text { Cambic/ } \\
\text { Argillic hor. } \\
\text { A - (B) - C }\end{array}$ & $A-B-C$ & $\begin{array}{l}\text { Stratified } \\
\qquad \text { A - C; } \\
\text { A - B - C }\end{array}$ & $\begin{array}{c}\text { Salic (Z)/Calcic } \\
\text { (Z) hor. } \\
\text { A - Bz - C/ } \\
\text { ABk - C }\end{array}$ & $\begin{array}{c}\mathrm{Az}-\mathrm{C} \\
\mathrm{A}-\mathrm{Bz}-\mathrm{C}\end{array}$ & $\begin{array}{l}\text { Gypsic (y) } \\
\text { hor. A - Cy }\end{array}$ & $\begin{array}{c}\mathrm{A}-\mathrm{C} \\
\text { (Stony) }\end{array}$ & $\begin{array}{c}\text { A - C } \\
\text { (bouldery) }\end{array}$ \\
\hline \multicolumn{9}{|c|}{ Fertility (f) } \\
\hline $\begin{array}{c}\text { CEC } \\
(\mathrm{cmol}(\mathrm{p}+) / \mathrm{kg}\end{array}$ & $40-16$ & $16-12$ & $16-12$ & - & - & - & - & - \\
\hline $\begin{array}{c}\text { Base } \\
\text { saturation } \\
(\%)\end{array}$ & $80+$ & $80+$ & $80-50$ & $50-35$ & $50-35$ & $35-15$ & $<15$ & - \\
\hline $\begin{array}{l}\text { Organic } \\
\text { carbon } \\
(0-15 \mathrm{~cm}) \\
\left(\mathrm{g} \cdot \mathrm{kg}^{-1}\right)\end{array}$ & $>10$ & $7.5-10$ & $5-7.5$ & $<5$ & $<5$ & - & - & - \\
\hline $\begin{array}{l}\text { Salinity EC } \\
\left(\mathrm{dS} \cdot \mathrm{m}^{-1}\right)\end{array}$ & $<1.0$ & $1-2$ & $2-4$ & $4-8$ & $8-15$ & $15-35$ & $35-50$ & $>50$ \\
\hline Gypsum & $0.3-2.0$ & $2-5$ & $5-10$ & $10-15$ & $15-25$ & $>25$ & - & - \\
\hline
\end{tabular}


Table 2. Soil-site suitability criteria (crop requirement) for wheat.

\begin{tabular}{|c|c|c|c|c|c|c|}
\hline \multirow{2}{*}{\multicolumn{2}{|c|}{ Soil-site characteristics }} & \multirow{3}{*}{ Unit } & \multicolumn{4}{|c|}{ Rating } \\
\hline & & & \multirow{2}{*}{$\begin{array}{l}\text { Highly } \\
\text { suitable } \\
\quad \text { S1 }\end{array}$} & \multirow{2}{*}{$\begin{array}{l}\text { Moderately } \\
\text { suitable } \\
\text { S2 }\end{array}$} & \multirow{2}{*}{$\begin{array}{l}\text { Marginally } \\
\text { suitable } \\
\text { S3 }\end{array}$} & \multirow{2}{*}{$\begin{array}{c}\text { Not } \\
\text { suitable } \\
\mathrm{N}\end{array}$} \\
\hline & & & & & & \\
\hline \multirow{2}{*}{$\begin{array}{l}\text { Climatic } \\
\text { regime }\end{array}$} & \multirow{2}{*}{$\begin{array}{l}\text { Mean temperature } \\
\text { in growing season }\end{array}$} & \multirow{2}{*}{${ }^{\circ} \mathrm{C}$} & \multirow{2}{*}{$20-25$} & $26-28$ & $29-34$ & $<14$ \\
\hline & & & & $18-19$ & $14-17$ & $>34$ \\
\hline \multicolumn{3}{|l|}{ Land quality } & \multicolumn{2}{|c|}{ Land characteristics } & & \\
\hline \multirow{2}{*}{$\begin{array}{l}\text { Moisture } \\
\text { availability }\end{array}$} & $\begin{array}{l}\text { Length of } \\
\text { growing period }\end{array}$ & Days & $>150$ & $120-150$ & $90-120$ & $<90$ \\
\hline & AWC & $\mathrm{mm} \cdot \mathrm{m}^{-1}$ & & & & \\
\hline $\begin{array}{l}\text { Oxygen } \\
\text { availability } \\
\text { to roots }\end{array}$ & Soil drainage & Class & $\begin{array}{l}\text { Well-drained } \\
\text { to moderately } \\
\text { well-drained }\end{array}$ & $\begin{array}{l}\text { Imperfectly } \\
\text { drained }\end{array}$ & $\begin{array}{l}\text { Poorly } \\
\text { drained }\end{array}$ & $\begin{array}{l}\text { Very poorly } \\
\text { drained; } \\
\text { excessively drained }\end{array}$ \\
\hline \multirow{3}{*}{$\begin{array}{l}\text { Nutrient } \\
\text { availability }\end{array}$} & Texture & Class & l, cl, sil, scl & sc, sic, c, ls, sicl, sl & $C+(45 \%-60 \%)$ & $\mathrm{C}++(>60 \%)$ \\
\hline & $\mathrm{pH}$ & $1: 2.5$ & $6.5-7.5$ & $7.6-8.5 ; 5.5-6.4$ & $8.6-10 ; 4.5-5.4$ & $<4.5 ;>10$ \\
\hline & OC & $\%$ & $0.6-0.7$ & $0.5-0.6$ & $0.3-0.5$ & $<0.3$ \\
\hline \multirow{2}{*}{$\begin{array}{l}\text { Rooting } \\
\text { conditions }\end{array}$} & Effective soil depth & $\mathrm{cm}$ & $65-100$ & $65-50$ & $50-25$ & $<25$ \\
\hline & Stoniness & $\%$ & $<15$ & $15-35$ & $>35$ & \\
\hline \multirow[t]{2}{*}{ Soil toxicity } & $\begin{array}{c}\text { Salinity } \\
\text { (EC saturation extract) }\end{array}$ & $\mathrm{dS} \cdot \mathrm{m}^{-1}$ & $<4.0$ & $4.0-6.0$ & $>6.0$ & \\
\hline & Sodicity (ESP) & $\%$ & $<15$ & $15-30$ & $30-40$ & $>40$ \\
\hline Erosion hazard & Slope & $\%$ & $<3$ & $3-<5$ & $5-10$ & $>10$ \\
\hline
\end{tabular}

$\mathrm{C}+=$ Clay (45 - 60 per cent), C++ = Clay $>60 \%$. Source: [25].

Table 3. Soil-site suitability criteria (crop requirement) for Sorghum.

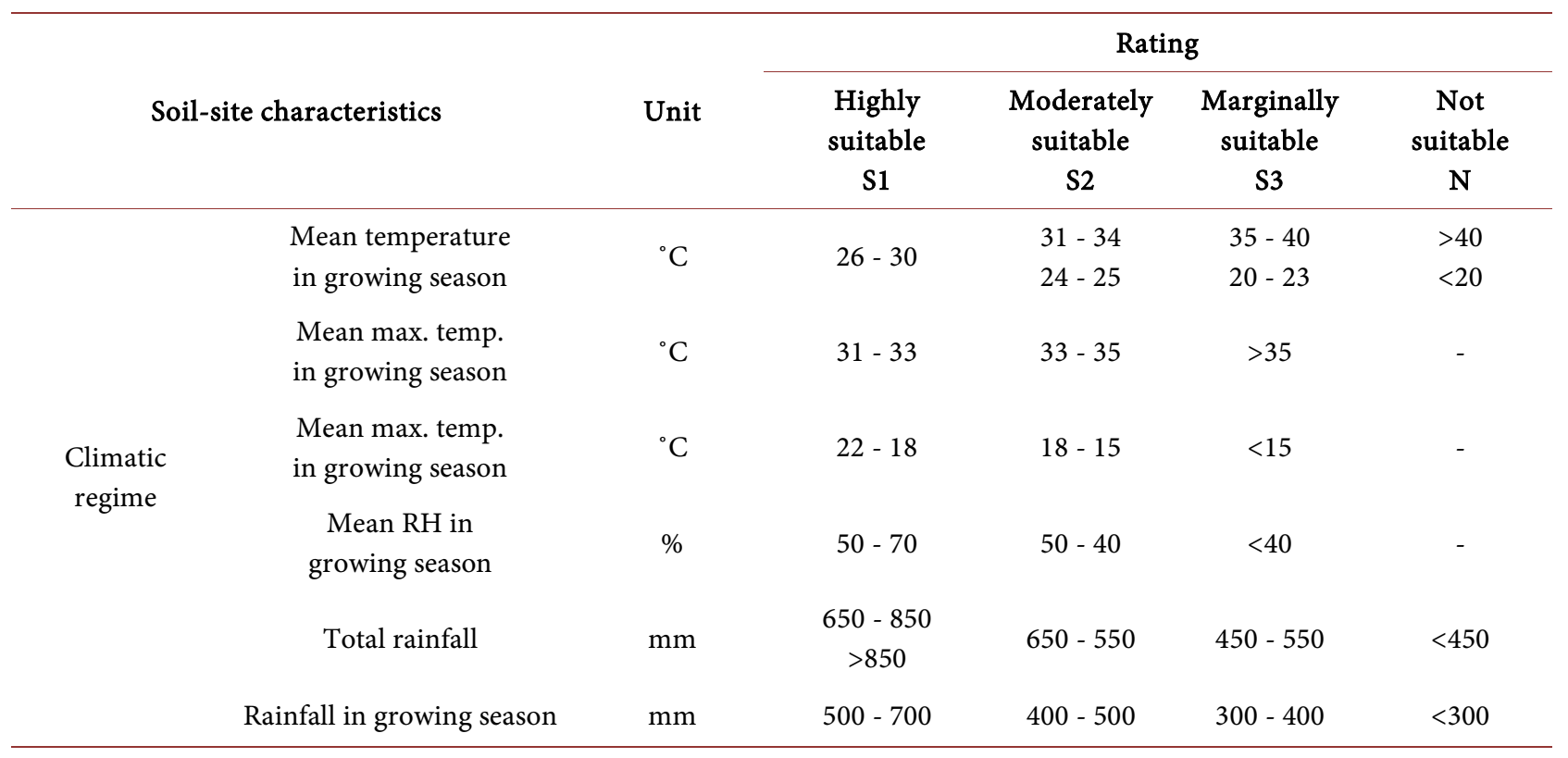




\section{Continued}

\begin{tabular}{|c|c|c|c|c|c|c|}
\hline Land quality & & & Land characteristi & & & \\
\hline \multirow{2}{*}{$\begin{array}{l}\text { Moisture } \\
\text { availability }\end{array}$} & Length of growing period & Days & $120-150$ & $120-90$ & $<90$ & - \\
\hline & AWC & $\mathrm{mm} \cdot \mathrm{m}^{-1}$ & $150-200$ & $100-150$ & $50-100$ & $<50$ \\
\hline \multirow{2}{*}{$\begin{array}{l}\text { Oxygen } \\
\text { availability } \\
\text { to roots }\end{array}$} & Soil drainage & Class & Well to moderate & Imperfect & Poor/Excessive & Very poor \\
\hline & $\begin{array}{l}\text { Water logging in } \\
\text { growing season }\end{array}$ & Days & $2-3$ & $3-4$ & $4-5$ & $>5$ \\
\hline \multirow{6}{*}{$\begin{array}{c}\text { Nutrient } \\
\text { availability }\end{array}$} & Texture & Class & $\mathrm{c}, \mathrm{cl}$, sicl, sc & 1, sil, sic & sl, ls & $\begin{array}{l}\text { s, fragmental } \\
\text { skeletal }\end{array}$ \\
\hline & $\mathrm{pH}$ & $1: 2.5$ & $6.0-8.0$ & $5.5-5.9$ & $<5.5$ & $>9.0$ \\
\hline & CEC & $\mathrm{cmol}(\mathrm{p}+) / \mathrm{kg}$ & $30-20$ & $20-10$ & $<10$ & \\
\hline & BS & $\%$ & $80-50$ & $50-35$ & $<35$ & \\
\hline & $\mathrm{CaCO}_{3}$ in root zone & $\%$ & $5-10$ & $10-25$ & $>25$ & \\
\hline & $\mathrm{OC}$ & $\%$ & $0.50-0.75$ & $0.50-0.20$ & $<0.20$ & \\
\hline \multirow{3}{*}{$\begin{array}{l}\text { Rooting } \\
\text { conditions }\end{array}$} & Effective soil depth & $\mathrm{cm}$ & $100-75$ & $50-75$ & $30-50$ & $<30$ \\
\hline & Stoniness & $\%$ & $5-15$ & $15-30$ & $30-60$ & $>60$ \\
\hline & Coarse fragments & Vol (\%) & $5-15$ & $15-40$ & $40-75$ & $>75$ \\
\hline \multirow[t]{2}{*}{ Soil toxicity } & $\begin{array}{c}\text { Salinity } \\
\text { (EC saturation extract) }\end{array}$ & $\mathrm{dS} \cdot \mathrm{m}^{-1}$ & $2-4$ & $4-8$ & $8-10$ & $>10$ \\
\hline & Sodicity (ESP) & $\%$ & $5-8$ & $8-10$ & $10-15$ & $>15$ \\
\hline Erosion hazard & Slope & $\%$ & $2-3$ & $3-8$ & $8-15$ & $>15$ \\
\hline
\end{tabular}

Source: [24]-[29].

\section{Results and Discussion}

\subsection{Soil Map and Soil Mapping Units}

A soil map is designed to show the distribution of soil types or other soil mapping units in relation to other prominent physical and cultural features of the earth's surface. The mapping units of soils are phases of soil series considering texture, depth, slope and erosion characteristics of the site. In the identification of soil mapping units of the study area, soil series, soil texture, soil depth, slope and erosion were used as inputting parameters.

The soil map shows four series namely, Singhanhalli (SGH), Bogur (BGR), Mugli (MGL) and Venkatapur (VKP) series (Figure 2(a)). These were mapped into seventeen mapping units at different phases of soil series with the help of Arc View Interface of ArcGIS 10.1 GIS software (Figure 2(b)). The mapping legend is presented as e.g., SGH-c-d4/Be1, numerator represents the name of the series (e.g., SGH-Singhanhalli), surface texture (c-clay) and depth of the soil $(\mathrm{d} 4-75$ to $100 \mathrm{~cm})$ and the denominator indicates slope $(\mathrm{B}-1$ to $3 \%)$ of the land and erosion status (e1-slight). Maps of one or more soil features were 


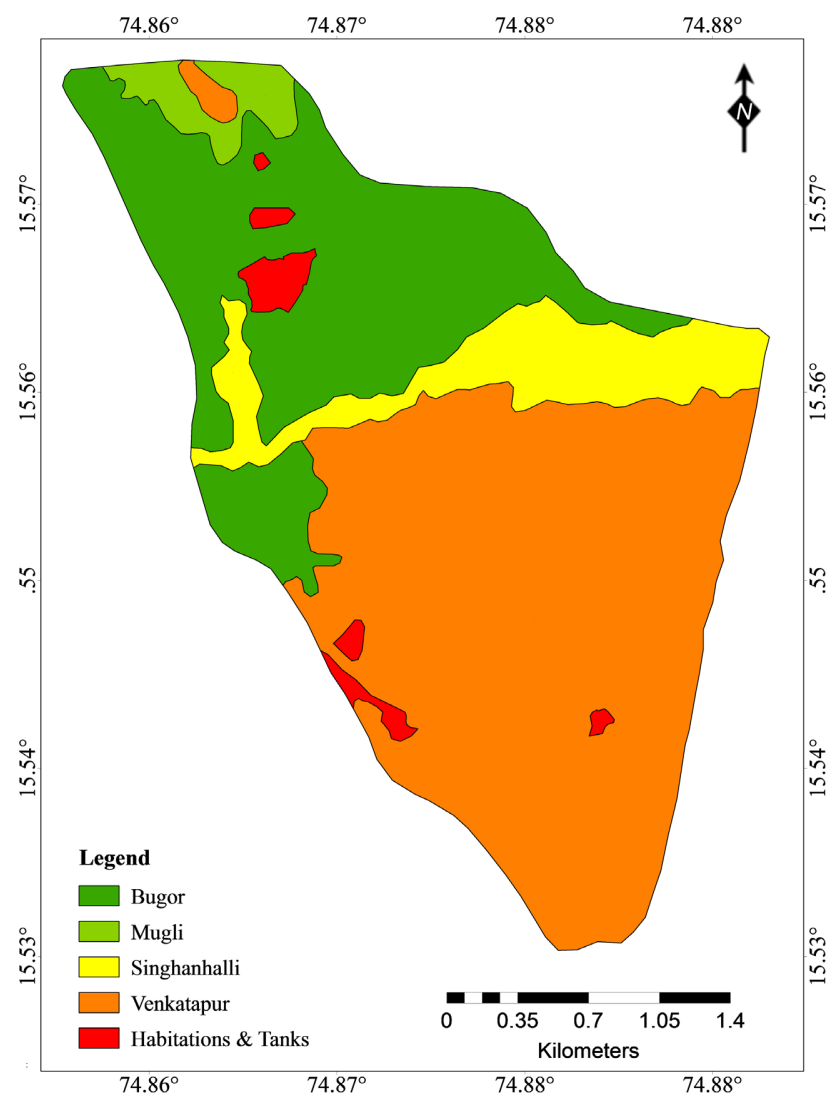

(a)

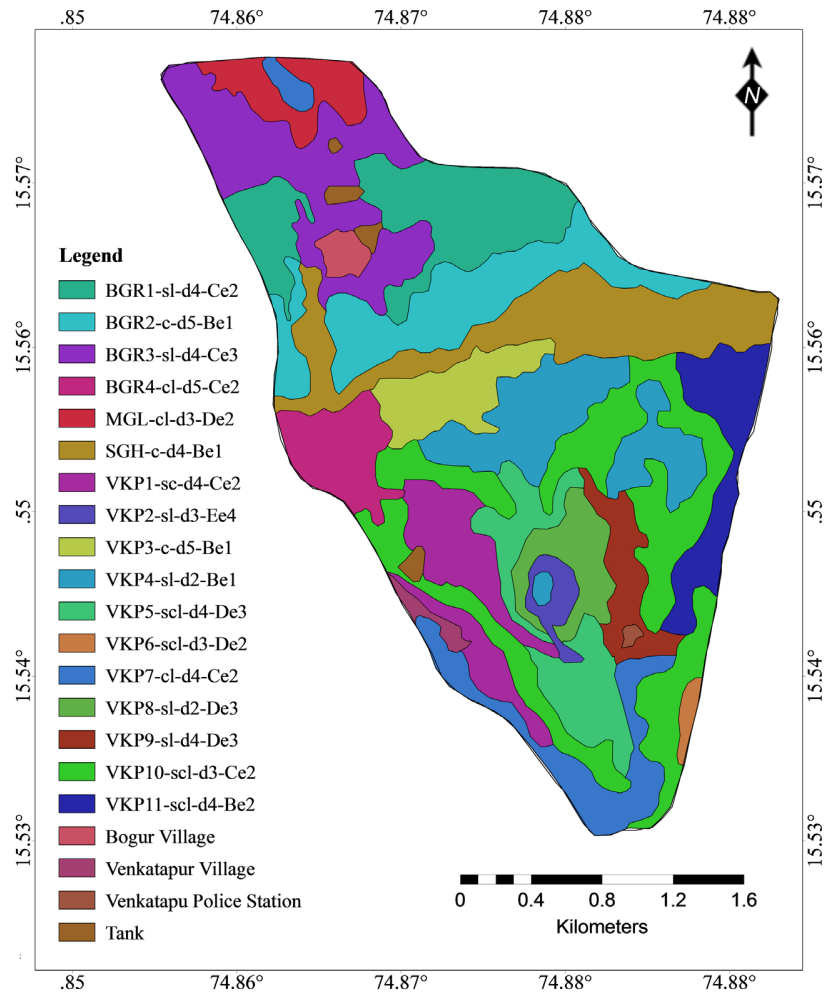

(b)

Figure 2. (a) Soil series map of study area; (b) Soil mapping units of study area. 
made directly from field observations and as well by selection and generalization from the soil map. The legend design and the kinds of mapping units for the study area were determined by the procedure and kind of survey as indicated by [26].

Singhanhalli series covers 78.5 ha (10.3\%) of the study area and were classified as Typic Haplusterts. They are deep, moderately well-drained clay soils located on very gentle slopes found in lowlands, associated with moderate to rapid permeability and slight erosion. Mugli series which cover 22.1 ha (2.9\%) were classified as Ultic Haplustalfs. They are moderately deep and moderately well-drained clay loam soils located on moderate slopes found in undulating midlands, associated with moderate to rapid permeability and moderate erosion. Bogur series covers 237.3 ha $(31.2 \%)$ and were classified into three families, namely, Typic Ustorthents, Typic Calciusterts and Ultic Haplustalfs. The Typic Ustorthents were deep and well-drained sandy loam soils located on gentle slopes found in undulating midlands, associated with rapid permeability and moderate erosion. The Typic Calciusterts were very deep, moderately well-drained clay soils located on very gentle slopes found in lowlands, associated with slow permeability and slight erosion. The Ultic Haplustalfs were very deep, well-drained clay loam soils located on gentle slopes found in lowlands, associated with rapid permeability and moderate erosion.

Venkatapur series covers 406.6 ha $(53.5 \%)$ of the study area and were classified into six families, namely, Typic Ustorthents, Typic Ustipsamments, Chromic Haplusterts, Typic Haplustalfs, Ultic Haplustalfs and Lithic Haplustalfs. The Typic Ustorthents were deep and well-drained sandy clay soils located on gentle slopes found in lowlands, associated with slow permeability and moderate erosion. The Typic Ustipsamments were deep and well-drained sandy loam soils located on steep slopes found in uplands, associated with rapid permeability and very severe erosion. The Chromic Haplusterts were deep and moderately well-drained clay soils located on very gentle slopes found in lowlands, associated with moderate to rapid permeability and slight erosion. The Typic Haplustalfs were shallow and well-drained sandy loam soils located on very gentle slopes found in uplands, associated with moderate to rapid permeability and slight erosion. The Ultic Haplustalfs were moderately deep to deep, moderately drained to well-drained clay loams and sandy clay loam soils located on very gentle to gentle and moderate slopes found in lowlands and undulating midlands, associated with moderate to rapid permeability and moderate to severe erosion. The Lithic Haplustalfs were shallow, moderately well-drained sandy loam soils located on moderate slopes found in uplands, associated with moderate to rapid permeability and severe erosion.

\subsection{Land Capability Classification}

Based on the soil-site characteristics of the study area, the soils were classified into four land capability classes (Table 4 and Figure 3 and Figure 4). These four land capability classes are discussed below: 


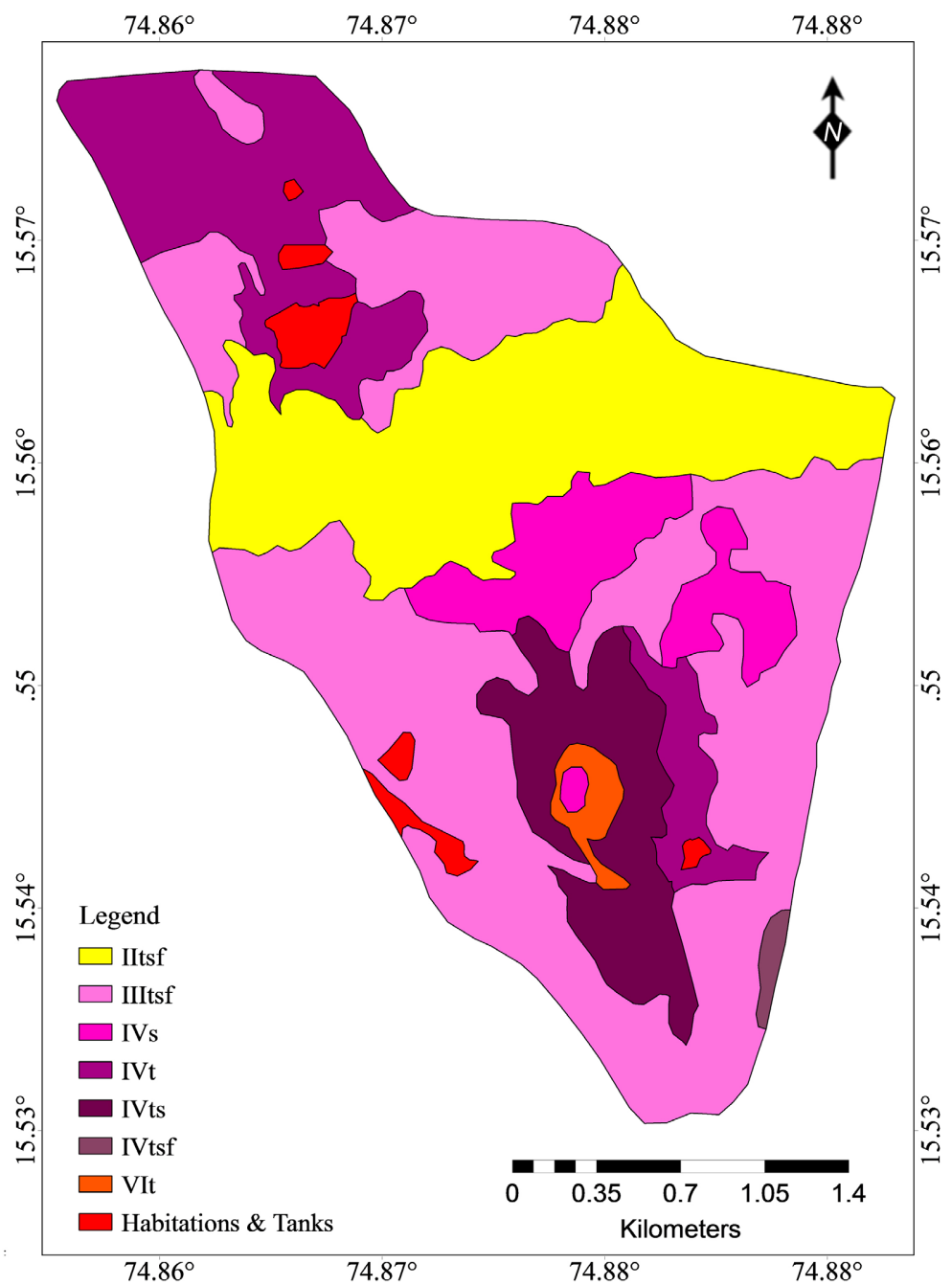

Figure 3. Land capability classes.

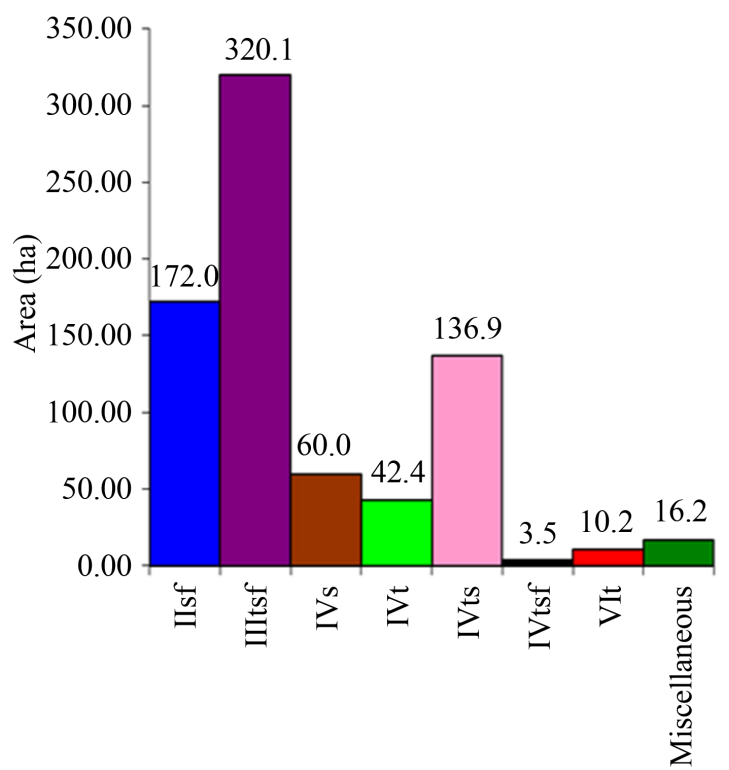

Figure 4. Extent of land capability classes. 
Table 4. Extent of land capability subclasses of Singhanhalli-Bogur micro-watershed.

\begin{tabular}{|c|c|c|c|}
\hline \multirow{2}{*}{ Mapping unit } & \multicolumn{3}{|c|}{ Land Capability } \\
\hline & Subclass & Area (ha) & $\%$ of study area \\
\hline SGH-c-d4/Be1 & \multirow{3}{*}{ IItsf } & \multirow{3}{*}{172.0} & \multirow{3}{*}{22.6} \\
\hline BGR2-c-d5/Be1 & & & \\
\hline VKP3-c-d5/Be1 & & & \\
\hline BGR1-sl-d4/Ce2 & \multirow{6}{*}{ IIItsf } & \multirow{6}{*}{320.1} & \multirow{6}{*}{42.1} \\
\hline BGR4-cl-d5/Ce2 & & & \\
\hline VKP1-sc-d4/Ce2 & & & \\
\hline VKP6-cl-d4/Ce2 & & & \\
\hline VKP5-scl-d3/Ce2 & & & \\
\hline VKP5-scl-d4/Be2 & & & \\
\hline MGL-cl-d3/De2 & \multirow{3}{*}{ IVt } & \multirow{3}{*}{115.6} & \multirow{3}{*}{15.2} \\
\hline BGR3-sl-d4/Ce3 & & & \\
\hline VKP8-sl-d4/De3 & & & \\
\hline VKP4-sl-d2/Be1 & IVs & 59.5 & 7.8 \\
\hline VKP5-scl-d4/De3 & \multirow[b]{2}{*}{ IVts } & \multirow[b]{2}{*}{63.7} & \multirow[b]{2}{*}{8.4} \\
\hline VKP7-sl-d2/De3 & & & \\
\hline VKP5-scl-d3/De2 & IVtsf & 3.5 & 0.5 \\
\hline VKP2-sl-d3/Ee4 & VIt & 10.2 & 1.3 \\
\hline
\end{tabular}

Note: SGH is Singhanhalli; BGR is Bogur; MGL is Mugli; VKP is Venkatapur; c is clay; cl is clay loam; sl is sandy loam; scl is sandy clay loam; $d$ is depth; B is slope class B; C is slope class $\mathrm{C}$; $\mathrm{D}$ is slope class $\mathrm{D}$; $\mathrm{E}$ is slope class $\mathrm{E}$; e is erosion; $\mathrm{t}$ is limitations relating to topography; $\mathrm{s}$ is limitations relating to soil conditions and $\mathrm{f}$ is limitations relating to fertility of the soil.

Class II: Soils in this class are referred to as good cultivable lands, which have limitations that restrict their use [24] [25] [26]. These soils are limited by one or more of factors such as: 1) moderate limitations which reduce choice of crop, 2) gentle slope (1\% to $5 \%), 3$ ) moderate erosion hazards, 4) inadequate soil depth, 5) less than ideal soil structure and workability, 6) slight to moderate alkaline or saline condition, 7) somewhat restricted drainage, 8) require moderate conservation practices to prevent deterioration and 9) capable of sustaining less intensive cropping systems.

The result showed that 172.0 ha (22.6\%) of the study area was occupied by land capability class II lands. These soils were moderate to rapidly permeable and moderately well-drained with slight limitations of slope, drainage, depth, texture, profile development, soil reaction, organic carbon and base saturation. In order to realize sustainable production of wheat and sorghum on these soils, the management practices may include terracing, strip cropping, contour-tillage, 
rotation, etc.

Class III: Soils in this class are referred to as moderately good cultivable lands, which have severe limitations that restrict their use [24] [25] [26]. These soils are limited by one or more of factors such as: 1) severe limitations which reduce the choice of crops, 2) moderately steep slope (5\% to $10 \%), 3$ ) high erosion hazards, 4) very slow water permeability, 5) shallow depth and restricted root zone, 6) low water holding capacity, 7) low fertility, 8) moderate alkalinity and salinity and 9) unstable structure.

The result showed that 320.1 ha $(42.1 \%)$ of the study area was occupied by land capability class III lands. These soils were moderate to rapidly permeable and moderately well-drained with moderate limitations of slope, erosion, depth, coarse fragments, profile development, organic carbon and base saturation. These soils require special conservation practices in order to cultivate wheat and sorghum and special management practices are required in addition to the management practices listed above for the Class II soils.

Class IV: Soils in this class are referred to as fairly good cultivable lands suitable for occasional cultivation, which have very severe limitations that restrict their use [24] [25] [26]. These soils are limited by one or more factors such as: 1) severe limitations which reduce the choice of crops, 2) severe erosion susceptibility, 3) steep slope, 4) severe erosion, 5) shallow soils, 6) low water holding capacity, 7) poor drainage and 8) severe alkalinity and salinity.

The result showed that 242.2 ha $(31.8 \%)$ of the study area was occupied by land capability class IV lands. These soils were moderate to rapidly permeable and moderately well-drained with severe limitation of slope, moderate to severe limitations of erosion and depth, profile development and base saturation; and moderate limitations of coarse fragments and organic carbon. For optimum production of wheat and sorghum on these soils, careful management practices are required.

Class VI: Soils in this class are referred to as non-cultivable lands located on steep slopes, highly erosion-prone with shallow soils [24] [25] [26]. They are limited by one or more factors such as: 1) extreme limitations of depth and slope and 2 ) severe erosion hazards, etc. The result showed that 10.2 ha (1.3\%) of the study area was occupied by Class VI lands. These soils were very severe limitations of slope. These lands area is unsuitable for cultivation of wheat and sorghum and hence, their use could be restricted to forestry, wildlife, grazing and silviculture and other non-agricultural land uses.

There was no class I lands in the study area. Major proportions of the study area belonged to class IIItsf followed by class IIsf, IVts, IVs, IVt, VIt and IVtsf.

\subsection{Soil-Site Suitability}

In the present study, the mapped soils of the study area were evaluated to assess their suitability for wheat and sorghum production and presented in Table 5(a) and Table 5(b) and Table 6 and Figure 5 and Figure 6. 
Table 5. (a) Soil-site suitability characteristics of soil mapping units of Singhanhalli-Bogur Microwatershed; (b) Soil-site suitability characteristics of soil mapping units of Singhanhalli-Bogur Microwatershed.

(a)

\begin{tabular}{|c|c|c|c|c|c|c|c|c|}
\hline \multirow[b]{2}{*}{ Mapping unit } & \multirow[b]{2}{*}{$\begin{array}{c}\text { Rainfall } \\
\text { (mm) }\end{array}$} & \multirow[b]{2}{*}{$\begin{array}{c}\text { LGP } \\
\text { (days) }\end{array}$} & \multicolumn{2}{|c|}{ Climate (c) } & \multirow[b]{2}{*}{$\begin{array}{c}\text { Mean } \\
\text { Temperature } \\
\left({ }^{\circ} \mathrm{C}\right)\end{array}$} & \multirow[b]{2}{*}{$\begin{array}{c}\text { Relative } \\
\text { Humidity } \\
\text { (\%) }\end{array}$} & \multirow{2}{*}{$\begin{array}{c}\text { Topography (t) } \\
\text { Slope (\%) }\end{array}$} & \multirow[b]{2}{*}{ Erosion } \\
\hline & & & $\begin{array}{c}\text { Maximum } \\
\text { Temperature } \\
\left({ }^{\circ} \mathrm{C}\right)\end{array}$ & $\begin{array}{c}\text { Minimum } \\
\text { Temperature } \\
\left({ }^{\circ} \mathrm{C}\right)\end{array}$ & & & & \\
\hline SGH-c-d4/Be1 & 755.2 & $150-180$ & 30.9 & 18.8 & 24.8 & 64.9 & Very gently sloping & Slight \\
\hline MGL-cl-d3/De2 & 755.2 & $150-180$ & 30.9 & 18.8 & 24.8 & 64.9 & Moderately sloping & Moderate \\
\hline BGR1-sl-d4/Ce2 & 755.2 & $150-180$ & 30.9 & 18.8 & 24.8 & 64.9 & Gently sloping & Moderate \\
\hline BGR2-c-d5/Be1 & 755.2 & $150-180$ & 30.9 & 18.8 & 24.8 & 64.9 & Very gently sloping & Slight \\
\hline BGR3-sl-d4/Ce3 & 755.2 & $150-180$ & 30.9 & 18.8 & 24.8 & 64.9 & Gently sloping & Severe \\
\hline BGR4-cl-d5/Ce2 & 755.2 & $150-180$ & 30.9 & 18.8 & 24.8 & 64.9 & Gently sloping & Moderate \\
\hline VKP1-sc-d4/Ce2 & 755.2 & $150-180$ & 30.9 & 18.8 & 24.8 & 64.9 & Gently sloping & Moderate \\
\hline VKP2-sl-d3/Ee4 & 755.2 & $150-180$ & 30.9 & 18.8 & 24.8 & 64.9 & Strongly sloping & Very severe \\
\hline VKP3-c-d5/Be1 & 755.2 & $150-180$ & 30.9 & 18.8 & 24.8 & 64.9 & Very gently sloping & Slight \\
\hline VKP4-sl-d2/Be1 & 755.2 & $150-180$ & 30.9 & 18.8 & 24.8 & 64.9 & Very gently sloping & Slight \\
\hline VKP5-scl-d4/De3 & 755.2 & $150-180$ & 30.9 & 18.8 & 24.8 & 64.9 & Moderately sloping & Severe \\
\hline VKP5-scl-d3/De2 & 755.2 & $150-180$ & 30.9 & 18.8 & 24.8 & 64.9 & Moderately sloping & Moderate \\
\hline VKP5-scl-d3/Ce2 & 755.2 & $150-180$ & 30.9 & 18.8 & 24.8 & 64.9 & Gently sloping & Moderate \\
\hline VKP5-scl-d4/Be2 & 755.2 & $150-180$ & 30.9 & 18.8 & 24.8 & 64.9 & Very gently sloping & Moderate \\
\hline VKP6-cl-d4/Ce2 & 755.2 & $150-180$ & 30.9 & 18.8 & 24.8 & 64.9 & Gently sloping & Moderate \\
\hline VKP7-sl-d2/De3 & 755.2 & $150-180$ & 30.9 & 18.8 & 24.8 & 64.9 & Moderately sloping & Severe \\
\hline VKP8-sl-d4/De3 & 755.2 & $150-180$ & 30.9 & 18.8 & 24.8 & 64.9 & Moderately sloping & Severe \\
\hline
\end{tabular}

(b)

\begin{tabular}{|c|c|c|c|c|c|c|c|c|c|c|}
\hline \multirow[b]{2}{*}{ Mapping unit } & \multirow{2}{*}{$\begin{array}{c}\text { Moistness } \\
(\mathrm{w})\end{array}$} & \multicolumn{5}{|c|}{ Physical conditions of soil (s) } & \multicolumn{3}{|c|}{ Soil fertility (f) } & \multirow{2}{*}{$\begin{array}{c}\text { Alkalinity } \\
\text { (n) } \\
\text { EC } \\
\left(\mathrm{dS} \cdot \mathrm{m}^{-1}\right)\end{array}$} \\
\hline & & $\begin{array}{l}\text { Depth } \\
(\mathrm{cm})\end{array}$ & Texture & $\begin{array}{l}\text { Coarse } \\
\text { fragments } \\
(\%)\end{array}$ & $\begin{array}{c}\text { Free } \\
\mathrm{CaCO}_{3} \\
(\%)\end{array}$ & $\mathrm{pH}$ & $\begin{array}{c}\mathrm{OC} \\
\left(\mathrm{g} \cdot \mathrm{kg}^{-1}\right)\end{array}$ & $\begin{array}{c}\text { CEC } \\
\left(\mathrm{cmol}(\mathrm{p}+) \mathrm{kg}^{-1}\right)\end{array}$ & $\begin{array}{l}\text { BS } \\
(\%)\end{array}$ & \\
\hline SGH-c-d4/Be1 & Well drained & Deep $(110+)$ & c & 5.2 & 2.4 & 7.7 & 4.4 & 34.9 & 75.8 & 0.14 \\
\hline MGL-cl-d3/De2 & $\begin{array}{c}\text { Well } \\
\text { drained }\end{array}$ & $\begin{array}{c}\text { Moderately } \\
\text { deep (73) }\end{array}$ & gcl & 23.1 & 8.0 & 6.5 & 8.6 & 18.3 & 64.8 & 0.08 \\
\hline BGR1-sl-d4/Ce2 & Well drained & Deep (80) & gsl & 41.9 & 2.1 & 6.4 & 6.4 & 18.6 & 66.4 & 0.12 \\
\hline BGR2-c-d5/Be1 & $\begin{array}{l}\text { Poorly } \\
\text { drained }\end{array}$ & $\begin{array}{l}\text { Very deep } \\
(130+)\end{array}$ & c & 8.1 & 9.4 & 8.1 & 2.3 & 41.0 & 84.5 & 0.11 \\
\hline BGR3-sl-d4/Ce3 & Well drained & Deep (106) & gsl & 41.8 & 8.5 & 7.0 & 5.0 & 23.3 & 58.7 & 0.09 \\
\hline BGR4-cl-d5/Ce2 & $\begin{array}{c}\text { Well } \\
\text { drained }\end{array}$ & $\begin{array}{l}\text { Very deep } \\
\quad(270)\end{array}$ & gcl & 22.6 & 1.8 & 6.7 & 4.9 & 17.3 & 63.0 & 0.08 \\
\hline VKP1-sc-d4/Ce2 & $\begin{array}{c}\text { Imperfectly } \\
\text { drained }\end{array}$ & $\begin{array}{c}\text { Deep } \\
(85)\end{array}$ & gsc & 22.1 & 0.5 & 7.1 & 11.9 & 29.1 & 66.0 & 0.13 \\
\hline
\end{tabular}




\section{Continued}

\begin{tabular}{|c|c|c|c|c|c|c|c|c|c|c|}
\hline VKP2-sl-d3/Ee4 & Well drained & Deep (78) & gsl & 24.1 & 1.5 & 5.5 & 10.4 & 25.4 & 49.0 & 0.09 \\
\hline VKP3-c-d5/Be1 & $\begin{array}{l}\text { Moderately } \\
\text { well drained }\end{array}$ & $\begin{array}{c}\text { Deep } \\
(120+)\end{array}$ & c & 11.5 & 1.4 & 7.9 & 5.3 & 44.0 & 85.1 & 0.13 \\
\hline VKP4-sl-d2/Be1 & Well drained & Shallow (43) & gsl & 25.3 & 2.2 & 7.5 & 5.5 & 29.9 & 74.2 & 0.33 \\
\hline VKP5-scl-d4/De3 & Well drained & Deep (86) & gscl & 24.7 & 0.4 & 7.0 & 7.3 & 27.7 & 54.4 & 0.13 \\
\hline VKP5-scl-d3/De2 & $\begin{array}{l}\text { Moderately } \\
\text { well drained }\end{array}$ & $\begin{array}{l}\text { Moderately } \\
\text { deep (56) }\end{array}$ & scl & 22.5 & 3.04 & 6.5 & 12.8 & 23.0 & 49.3 & 0.11 \\
\hline VKP5-scl-d3/Ce2 & $\begin{array}{c}\text { Well } \\
\text { drained }\end{array}$ & $\begin{array}{l}\text { Moderately } \\
\text { deep (70) }\end{array}$ & gscl & 28.9 & 1.8 & 6.1 & 11.7 & 27.3 & 49.4 & 0.14 \\
\hline VKP5-scl-d4/Be2 & Well drained & Deep (110) & gscl & 23.5 & 4.9 & 6.0 & 7.0 & 26.0 & 58.7 & 0.11 \\
\hline VKP6-cl-d4/Ce2 & $\begin{array}{l}\text { Moderately } \\
\text { well drained }\end{array}$ & $\begin{array}{c}\text { Deep } \\
(80)\end{array}$ & gcl & 26.5 & 1.2 & 6.5 & 7.1 & 24.8 & 48.5 & 0.13 \\
\hline VKP7-sl-d2/De3 & $\begin{array}{l}\text { Moderately } \\
\text { well drained }\end{array}$ & $\begin{array}{c}\text { Shallow } \\
(40)\end{array}$ & gsl & 17.5 & 1.9 & 6.3 & 11.1 & 24.9 & 54.6 & 0.10 \\
\hline VKP8-sl-d4/De3 & Well drained & Deep (100) & gsl & 25.0 & 3.3 & 6.1 & 16.4 & 28.7 & 52.1 & 0.10 \\
\hline
\end{tabular}

Table 6. Status of soil-site suitability for wheat and sorghum.

\begin{tabular}{|c|c|c|}
\hline \multirow{2}{*}{ Mapping unit } & \multicolumn{2}{|c|}{ Suitability subclasses } \\
\hline & Wheat & Sorghum \\
\hline SGH-c-d4/Be1 & S3f & S2efn \\
\hline MGL-cl-d3/De2 & S3e & S3e \\
\hline BGR1-sl-d4/Ce2 & S2e & S3es \\
\hline BGR2-c-d5/Be1 & S3f & S3esfn \\
\hline BGR3-sl-d4/Ce3 & S3ef & S3es \\
\hline BGR4-cl-d5/Ce2 & S3f & S3e \\
\hline VKP1-sc-d4/Ce2 & S2en & S3en \\
\hline VKP2-sl-d3/Ee4 & \multicolumn{2}{|c|}{ Non-cultivable land (NTE) } \\
\hline VKP3-c-d5/Be1 & S2sfn & S3n \\
\hline VKP4-sl-d2/Be1 & S2sfn & S3sn \\
\hline VKP5-scl-d4/De3 & S3e & S3e \\
\hline VKP5-scl-d3/De2 & S3e & S3e \\
\hline VKP5-scl-d3/Ce2 & S3ef & S3e \\
\hline VKP5-scl-d4/Be2 & S2ef & S3t \\
\hline VKP6-cl-d4/Ce2 & S2ef & S3e \\
\hline VKP7-sl-d2/De3 & S3e & N2es \\
\hline VKP8-sl-d4/De3 & S3e & S3es \\
\hline
\end{tabular}

Note: SGH is Singhanhalli; BGR is Bogur; MGL is Mugli; VKP is Venkatapur; c is clay; cl is clay loam; sl is sandy loam; scl is sandy clay loam; $d$ is depth; B is slope class $B$; C is slope class C; D is slope class D; E is slope class E; $\mathrm{S}$ is suitability; $\mathrm{N}$ is not suitable; NTE is not to be evaluated for crop production; e is erosion; $t$ is limitations relating to topography; $s$ is limitations relating to soil conditions, $\mathrm{f}$ is limitations relating to fertility and $\mathrm{n}$ is limitations relating to alkalinity. 


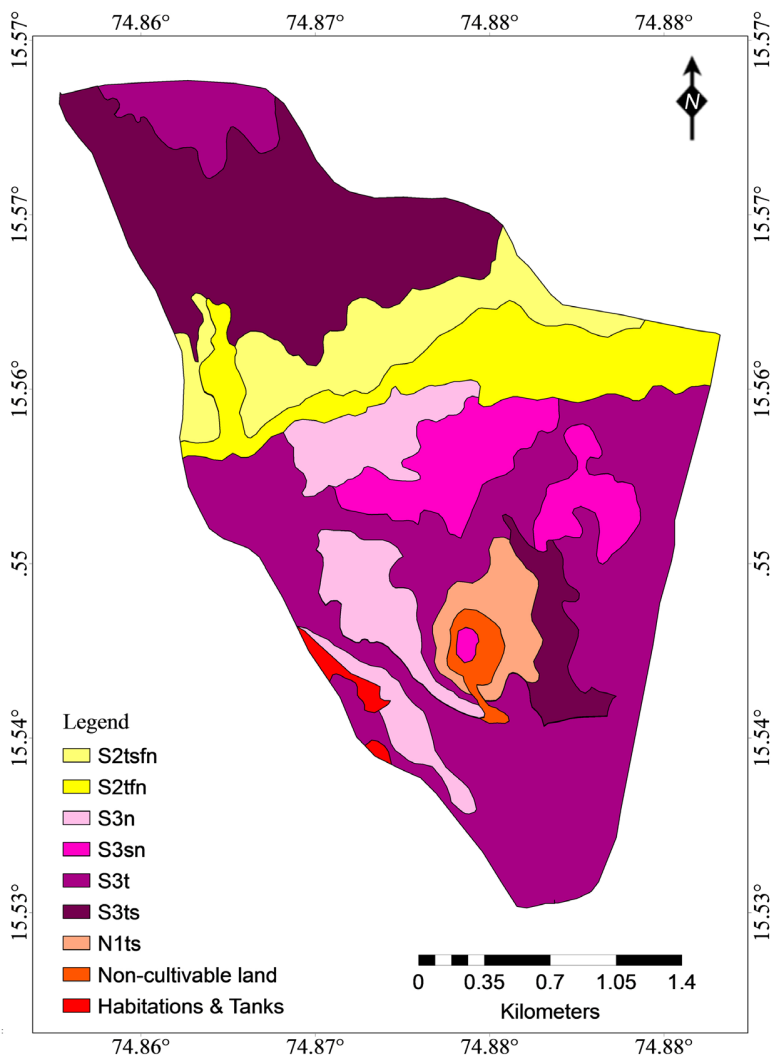

Figure 5. Soil suitability for wheat.

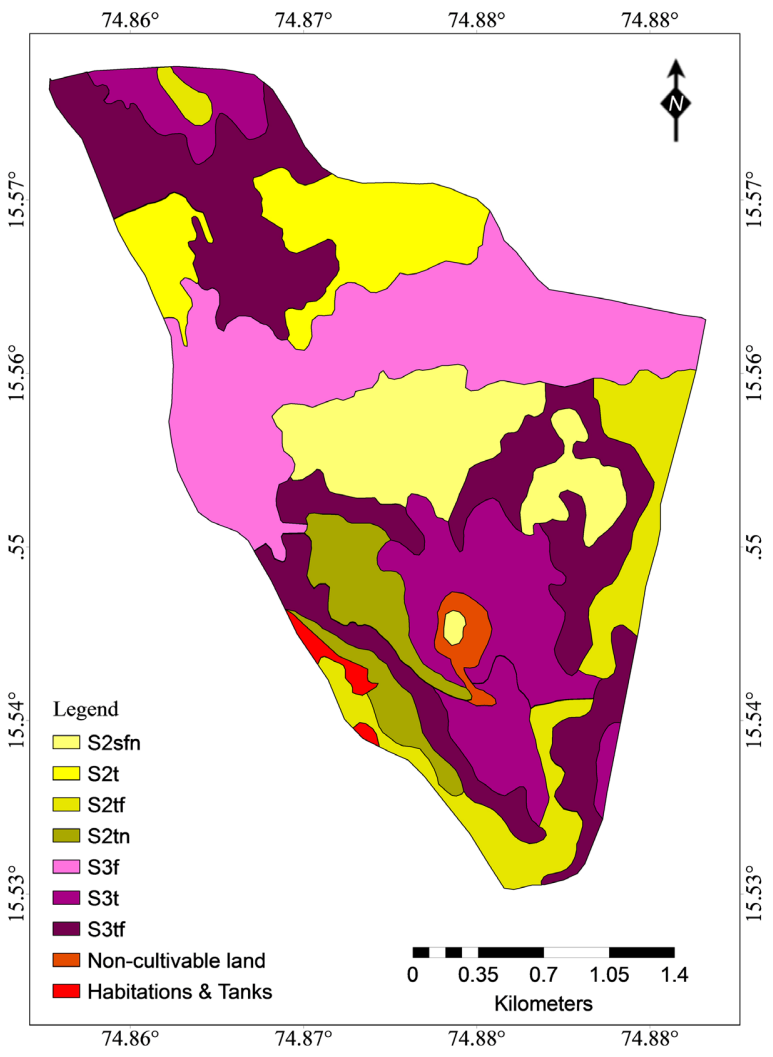

Figure 6. Soil suitability for sorghum. 


\subsubsection{Wheat (Triticum aestivum L.)}

Wheat is the world's number one cereal crop. It is an annual crop and a very important winter crop contributing about $32 \%$ of the total food grain production in India [27]. The soil-site suitability assessment for wheat revealed that about 270.3 ha $(35.5 \%)$ of the study area is moderately suitable due to slight to moderate limitations ranging from slope, erosion, $\mathrm{pH}$ and base saturation, whereas 436.9 ha $(57.4 \%)$ is marginally suitable for wheat due to moderate to severe limitations ranging from slope, erosion, $\mathrm{pH}$ and base saturation (Figure 5).

The result revealed that the slope, erosion, texture, $\mathrm{pH}$, organic carbon and base saturation are the major constraints that could influence the growth and productivity of wheat in the study area. Overall, the soils are highly suitable for wheat production with respect to rainfall $(755.5 \mathrm{~mm})$, length of growing period (150 - 180 days), depth (deep to very deep), drainage (moderately drained to well drained), electrical conductivity and $\mathrm{CaCO}_{3}$ content $(0.4 \%-9.4 \%)$. According to [28] [29], wheat grows well in well-drained soil with $\mathrm{pH}$ range of 6 to 8 . These results are in conformity with earlier reports that stated that optimum mean maximum temperature of $25^{\circ} \mathrm{C}$ and mean minimum temperature of $12^{\circ} \mathrm{C}$, annual rainfall of 250 to $1800 \mathrm{~mm}$ [28] [29] [30] [31] [32]; soils with good drainage, depth of 65 to $100 \mathrm{~cm}$ and organic carbon of $0.6 \%$ to $0.7 \%$ [33] [34] [35] are highly suitable for wheat.

The crop's potential yield (2.98 tonnes/ha) is achievable if erosion, $\mathrm{pH}$, organic carbon and base saturation constraints, as well as deficiencies of major and micronutrients, are addressed. In view of this, farmers growing this crop should take note of these constraints if high yields are to be achieved.

\subsubsection{Sorghum (Sorghum Bicolor L. Moench)}

The soil-site suitability assessment for sorghum revealed that about 78.5 ha $(10.3 \%)$ is moderately suitable due to moderate limitations ranging from erosion and organic carbon. About 633.4 ha (83.3\%) is marginally suitable due to moderate to severe limitations ranging from temperature, relative humidity, slope, erosion, drainage, texture and free $\mathrm{CaCO}_{3}$ while $22.3 \mathrm{ha}$ (2.9\%) is permanently not suitable due to severe limitations ranging from slope, erosion, depth and texture (Figure 6).

It was observed that the major constraints that could limit sorghum production in the study area are slope, erosion, depth, texture, coarse fragments, organic carbon, cation exchange capacity and base saturation. The rainfall (755.5 $\mathrm{mm}$ ), length of growing period (150 - 180 days), temperature (30.9), relative humidity (64.9), drainage (moderately drained to well-drained), $\mathrm{pH}$ (5.5 - 8.1), electrical conductivity and $\mathrm{CaCO}_{3}$ content $(0.4-9.4)$, are shown to be favourable for sorghum production. This confirms earlier work conducted by [19] [36] [37] [38] [39] [40]. It is however expected that the potential yield of sorghum could be achievable in the study area if the major constraints such as erosion, organic carbon, cation exchange capacity and base saturation as well as deficiencies of major and micronutrients are addressed. Through these efforts, soils could be 
made moderately suitable for the crop.

\section{Conclusion}

The major portion of the study area is class III lands, which are marginally suitable for the cultivation of crops but very suitable for other uses like wildlife, forestry and grazing. However, these lands cannot be put under intensive and very intensive cultivation. The second-largest area is occupied by class IV lands which are fairly suitable for cultivation. These lands can be used for limited cultivation, but are most suitable for wildlife, forestry and grazing. Next are the class II lands, which can be used for all types of cultivation (except for very intensive cultivation) in addition to wildlife, forestry and grazing. However, since class II lands are limited, they should be reserved purely for the cultivation of wheat and sorghum. Class VI lands occupy only a very small area. Because of the very severe limitations of slope in these lands, they are recommended for wildlife, forestry and grazing. The soil suitability ranged from moderately suitable to permanently not suitable. The soils were more suitable for wheat than sorghum.

\section{Conflicts of Interest}

The authors declare no conflicts of interest regarding the publication of this paper.

\section{References}

[1] Klingebiel, A.A. and Montgomery, P.H. (1961) Land Capability Classification. U.S. Government Printing Office, Washington DC.

[2] Food and Agriculture Organization of the United Nations (1976) A Framework for Land Evaluation. FAO Soils Bulletin No. 32, Food and Agriculture Organization of the United Nations, Rome, $72 \mathrm{p}$.

[3] Binita, N.K., Dasog, G.S. and Patil, P.L. (2009) Soil Fertility Mapping in Ghataprabha Left Bank Canal Ommand Area of North Karnataka by GIS technique, Karnataka. Karnataka Journal of Agricultural Sciences, 22, 73-76.

[4] Krishnan, P., Nair, K.M., Naidu, L.G.K., Srinivas, S., Artikoyal, Nasre, R.A., Ramesh, M. and Gajbhiye, K.S. (2004) Land, Soil and Land Use of Lakshadweep Coral Islands. Journal of the Indian Society Soil Science, 52, 226-231.

[5] Sharma, A. (2010) Integrating Terrain and Vegetation Indices for Identifying Potential Soil Erosion Risk Area. Geo-Spatial Information Science, 13, 201-209. https://doi.org/10.1007/s11806-010-0342-6

[6] Singh, B.T., Devi, N.K., Kumar, B.Y., Bishworjit, N., Singh, N.K.L. and Singh, H.A. (2013) Characterization, and Evaluation for Crop Suitability in Lateritic Soils. African Journal of. Agricultural Research, 8, 4628-4636. https://doi.org/10.5897/AJAR12013.7309

[7] Naidu, L.G.K. (2002) Economic Land Evaluation of Garrakahalli Microwatershed. In: Ramesh Kumar, S.C., et al., Eds., Economic Land Evaluation for Sustainable Land Management of Watersheds in Different Agro-Climatic Zones of Karnataka, Vol. 1, Tech. Report No. 582, National Bureau of Soil Survey and Land Use planning, Nagpur.

[8] Naidu, L.G.K. and Hunsigi, G. (2001) Application and Validation of FAO Frame- 
work and Soil Potential Ratings for Land Suitability Evaluation of Sugarcane Soils of Karnataka. Agropedology, 11, 91-100.

[9] Patil, P.L., Vinay, L. and Dasog, G.S. (2011) Land Evaluation of Bhanapur Micro-Watershed in Northern Dry Zone of Karnataka. Agropedology 21, 10-16.

[10] Pulakeshi, H.B.P., Patil, P.L. and Dasog, G.S. (2014) Characterization and Classification of Soil Resources Derived from Chlorite Schist in Northern Transition Zone of Karnataka. Karnataka Journal Agricultural Sciences, 27, 14-21.

[11] Ravikumar, M.A. (2004) Soil Resource Characterization of 48A Distributary of Malaprabha Right Bank Command for Sustainable Land Use Planning. Master's Dissertation in Agriculture, University of Agricultural Sciences, Dharwad.

[12] Ravikumar, M.A., Patil, P.L. and Dasog, G.S. (2009a) Soil Resource Characterization, Classification and Mapping of 48A Distributary of Malaprabha Right Bank Command, Karnataka for Land Use Planning. Karnataka Journal of Agricultural Sciences, 22, 81-88.

[13] Ravikumar, M.A., Patil, P.L. and Dasog, G.S. (2009b) Land Evaluation of 48A Distributary of Malaprabha Right Bank Command of Karnataka for Sustainable Land Use Planning. Karnataka Journal of Agricultural Sciences, 22, 89-94.

[14] Vinay, L. (2007) Characterization and Classification of Soil Resource of Bhanapur Microwatershed (Koppal District) for Land Evaluation. Master's Dissertation in Agriculture, University of Agricultural Sciences, Dharwad.

[15] Tumbal P. and Patil P.L. (2015) Characterization and Classification of Soil Resources of Balapur Micro-Watershed. Karnataka Journal of Agricultural Sciences, 28, 510-517.

[16] Mini, V., Patil, P.L. and Dasog, G.S. (2007) Characterization and Classification of Soils of Pilot Site in Coastal Agro-Ecosystem of North Karnataka. Agropedology, 17, 59-67.

[17] Mohan, M.M, Babu, M.V.S., Reddy, M. and Vijaya Sai (2013) Characterization of Soils of Hanumankoppa Microwatershed in Northern Transitional Zone of Karnataka. Progressive Agriculture, 13, 4-10.

[18] Pillai, M.Y. and Natarajan, A. (2004) Characterization and Classification of Dominant Soils of Parts of Garakahalli Watershed Using Remote Sensing Technique. The Mysore Journal of Agricultural Sciences, 38, 193-200.

[19] Naidu, L.G.K. (2002) Characterization of Sugarcane Soils of Karnataka. Agropedology, 12, 157-163.

[20] Khadse, G.K. and Gaikwad, S.T. (1995) Soil Based Agro Technology Transfer: A Case Study. Agroecology, 5, 91-96.

[21] Amara Denis, M.K., Patil, P.L., Dasog, G.S. and Manjunath. M.V. (2013) Rainfall Erosivity (R-Factor) Estimation for Singhanhalli-Bogur Microwatershed in Northern Transition Zone of Karnataka. Research Journal of Agricultural Sciences, 4, 644-647.

[22] Soil Survey Staff (2000) Soil Survey Manual. U.S. Department of Agriculture Handbook No. 18, Soil Conservation Service, Washington DC.

[23] Soil Survey Staff (2012) Keys to Soil Taxonomy. 12th Edition, United States Department of Agriculture Natural Resource Conservation Service, Washington DC.

[24] National Bureau of Soil Survey and Land Use planning (1994) Proceedings of National Meet on Soil-Site Suitability Criteria for Different Crops. NBSS\&LUP Publishing, Nagpur, 32 p.

[25] Sehgal, J. L. (1996) Pedology-Concepts and Application. Kalyani Publishers, New 
Delhi.

[26] Dent, D. and Young, A. (1981) Soil Survey and Land Evaluation. George Allen and Unwin Publication, London.

[27] Mohan, M.M., et al. (2013) Characterization of Soils of Hanumankoppa Microwatershed in Northerntransitional Zone of Karnataka. Progressive Agriculture, 13, 4-10

[28] ICAR (Indian Council of Agricultural Research) (1997) Handbook of Agriculture. Indian Council of Agricultural Research. New Delhi, 744-754.

[29] Naidu, L.G.K., Ramamurthy, V., Challa, O., Hedge, R. and Krishnan, P. (2006) Manual on Soil Suitability Criteria for Major Crops. Technical Bulletin No. 129, NBSS \& LUP Publishing, Nagpur.

[30] Malleswari, S., Nataraja, K.C. and Gopinath K.A. (2010) Prediction of Chilli Yields based on Soil Nutrient Status under Rainfed Conditions of Dharwad District, Karnataka. Indian Journal of Dryland Agricultural Research and Development, 25, 106-110.

[31] Pulakeshi, H.B.P., Patil, P.L., Dasog, G.S., Radder, BM. and Mansur, C.P. (2012) Mapping nutrients status by geographic information system (GIS) in Mantagani village under northern transition zone of Karnataka. Karnataka Journal of Agricultural Sciences, 25, 232-235.

[32] Ravikumar, M.A., Patil, P.L. and Dasog, G.S. (2007) Mapping of Nutrients Status of 48A Distributary of Malaprabha Right Bank Command of Karnataka by GIS Technique. I-Major Nutrients. Karnataka Journal of Agricultural Sciences, 20, 735-737.

[33] Bhaskar, K.S., Gaikwad, S.T. and Anantha Rao, D. (1996) Soil-Site Suitability Evaluation for Wheat: A Case Study. Agropedology, 6, 89-94.

[34] Srikanth, K.S., Patil, P.L., Dasog, G.S. and Hebsur, N.S. (2008) Mapping of Micronutrients Status in Black and Red Soils of a Microwatershed in Northern Dry Zone of Karnataka. Karnataka Journal of Agricultural Sciences, 21, 386-390.

[35] Tamgadge, D.B., Gajbhiye, K.S. and Bankar, W.V. (2002) Evaluation of Soil Suitability for Paddy Cultivation in Chattisgarh-A Parametric Approach. Journal of the Indian Society of Soil Sciences, 50, 81-88.

[36] Dasog, G.S. and Patil, P.L. (2011) Genesis and Classification of Black, Red and Lateritic Soils of North Karnataka. In: Patil, C.V., Kotur, S.C., Dasog, G.S. and Channal, H.T., Eds., Special Publication on Soil Science Research in North Karnataka, 76th Annual Convention of ISSS, Chapter of ISSS, Dharwad, 1-10.

[37] Dhanya V.M, Patil, P.L. and Dasog, G.S. (2009) Identification of Soil Fertility Constraints of a Pilot Site in Coastal Agro Eco System of Karnataka by GIS Technique, Karnataka. Karnataka Journal of Agricultural Sciences, 22, 77-80.

[38] Ravikumar, P. and Somashekar, R.K. (2013) Evaluation of Nutrient Index Using Organic Carbon, Available P and Available K Concentrations as a Measure of Soil Fertility in Varahi River Basin, India. Proceedings of the International Academy of Ecological and Environmental Sciences, 3, 330-343.

[39] Sannappa, B. and Manjunath, K.G. (2013) Fertility Status of Soils in the Selected Regions of the Western Ghats of Karnataka. India School Academy Journal of Biosciences, 1, 200-208.

[40] Shamsudheen, M., Dasog, G.S. and Patil, P.L. (2005) Characterization and Classification of Some Forest Soils of North Karnataka. Agropedology, 15, 86-89. 